\title{
Incomplete Acquisition and Verb Placement in Heritage
}

\section{Scandinavian}

\author{
Ida Larsson and Janne Bondi Johannessen \\ Stockholm University and University of Oslo
}

\section{Introduction}

There is well known variation in the Scandinavian languages with respect to verb placement in embedded clauses (see e.g. Holmberg \& Platzack 1995, Bobaljik 2002, Thráinsson 2010, Heycock et al. 2012 inter alia). In the modern Mainland Scandinavian languages, the finite verb follows negation in relative clauses and embedded questions (henceforth V-in-situ ). In Icelandic, on the other hand, the verb moves across negation to a position in the T-domain (henceforth V-to-T movement); see the simplified structure in (1). Older stages of Mainland Scandinavian pattern with Icelandic.

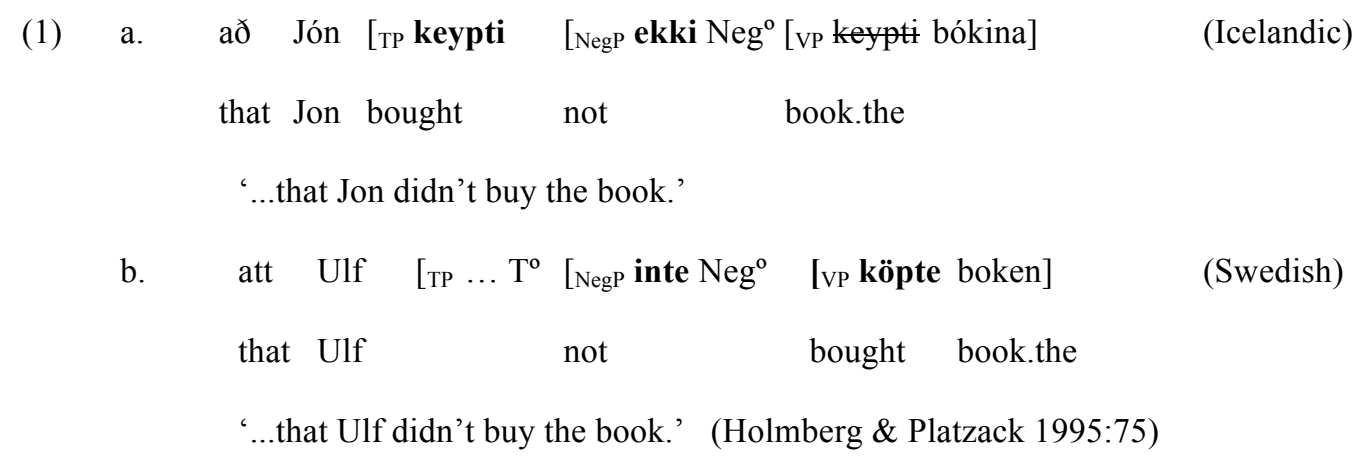


Much of the discussion of how this difference should be understood has revolved around the role of verb agreement, and on how V-to-T movement was lost in the history of Mainland Scandinavian (e.g. Falk 1993, Sundquist 2002, Håkansson 2013) and is in the final stages in the process of being lost in Faroese (Heycock et al. 2012, 2013). There is now some consensus that a biconditional between verb agreement and verb movement cannot be maintained: verb movement is sometimes possible without verb agreement.

In this paper, we study a development whereby heritage language varieties of Norwegian and Swedish undergo the opposite change from a grammar without V-to-T movement to a grammar with V-to-T movement, but without any concomitant change in verb morphology. The focus is on embedded clauses, but for a fuller picture of verb placement in Heritage Scandinavian we also briefly discuss verb placement in main clauses. We contrast Heritage Norwegian and Swedish (henceforth Heritage Scandinavian) with Norwegian and Swedish as spoken in Norway and Sweden, and by the speakers that immigrated to America in the period 1820-1920. For convenience, we refer to these latter varieties collectively as European Scandinavian (although only Norwegian and Swedish are included). The language spoken by the early, first-generation emigrants, we refer to as Emigrant Scandinavian; we will see that in the relevant respects, Emigrant Scandinavian is identical to European Scandinavian.

The study of Emigrant Scandinavian is based on the recordings by Einar Haugen in the 1930s and 1940s (Norwegian) and Folke Hedblom in the 1960s (Swedish). For Heritage Scandinavian, we use recordings made by the present author Johannessen and her colleagues Signe Laake and Arnstein Hjelde from 2010-2012 (Norwegian), and by the present author Larsson and colleagues in the project Swedish in America in 2011-2012. The recordings mainly consist of spontaneous production (interviews and conversations) (see Johannessen \& Laake (2011) and the website Norwegian in America on the Norwegian recordings, and 
Andréasson et al. 2013 and Larsson et al. to appear on the Swedish recordings). In this study, we restrict the discussion to speakers that have Heritage Scandinavian as L1 (see further Larsson \& Johannessen to appear). The speakers are all adults, and most of them are (well) over 70 years old.

The paper is organized as follows. Section 2 gives some background information on the Scandinavian emigration to America, and a brief account of the language and dialect situation amongst the immigrants. It also lays out the main theoretical views on bilingualism in a heritage language setting, focussing on the concepts of acquisition and attrition. In Section 3 we present the word order facts of main and subordinate clauses, between which there is an asymmetry both in European and Emigrant Scandinavian. Section 4 discusses verb placement in these two clause types in Heritage Scandinavian. Here, we show that verb placement in embedded clauses in Heritage Scandinavian differ from European Scandinavian, and also that there are some differences in main clauses for a number of heritage speakers. In Section 5, we relate the change in Heritage Scandinavian to the specific situation of the heritage language, showing the change in main clauses must be due to individual attrition, while the change in embedded clauses is best explained as incomplete acquisition. The latter analysis is supported by the fact that the word order data are exactly parallel in Heritage Scandinavian and in children learning European Scandinavian as an L1. In Section 6, we briefly discuss how the concept of incomplete acquisition can be understood theoretically.

\section{Sources for variation and change in Heritage Scandinavian}

1300000 Swedes and 800000 Norwegians emigrated to America between 1820 and 1920; most went to the Midwest and settled as farmers, often in communities where there were 
already others from the same area of their homeland. Norwegian and Swedish communities therefore kept the language from home for many years, and through several generations. This language was used in public life, in schools and church, and there were many newspapers, too. Still today, there are descendants of these immigrants that continue to speak Norwegian and Swedish, and who have a Scandinavian language as their first language. We use the term Heritage Scandinavian to refer to the Norwegian or Swedish acquired as a first language in a naturalistic setting, but in a society where this is not the dominant language. For heritage speakers, the first language will generally not continue to be the strongest, primary language after school start (cf. e.g. Polinsky 2008 and references there). For present-day Heritage Scandinavian speakers in America, English is always the primary language, and Scandinavian is weaker, secondary, and used only in a restricted set of situations and among a limited group of speakers (typically family members).

Heritage Norwegian and Swedish differ from European Norwegian and Swedish in several respects (see e.g. Haugen 1953, Hasselmo 1974, Hjelde 1996a,b and the papers in Johannessen \& Salmons 2012). The differences have several sources (cf. Larsson et al. to appear), viz. dialect contact, transfer from English and bilingualism. In this section, we give a very brief overview of the sources for variation. We first consider transfer between varieties of Scandinavian and English, before we address questions relating to the bilingualism of heritage speakers, and the fact that Scandinavian is not the dominant language. Here, where we are concerned with verb placement and the individual grammatical system of the heritage speakers (and not primarily e.g. the sociolinguistic aspects of Heritage Scandinavian), it will be particularly important to distinguish between variation and change that depends on how the heritage language is acquired, and variation and change that rather depend on language loss (attrition) in the individual. 


\subsection{Dialect, language contact, and transfer}

Emigration led people from different Scandinavian dialect areas to meet and become neighbors. Contact between dialects is therefore one source for change in American Scandinavian. The development of American Scandinavian can at least to some degree be understood in terms of koineization (cf. e.g. Kerswill 2003, Johannessen \& Laake to appear and Hjelde to appear on Norwegian, Larsson et al. to appear on Swedish and Boas 2009 and Nützel \& Salmons 2011 on German). The situation is however different for Swedish and Norwegian, relating to the fact that Swedish started to develop a spoken standard (based partly on the written standard) well before the time of emigration. In American Swedish, some dialect features can be retained in the language of individual speakers, but e.g. dialectal vocabulary has largely been lost, and the dialects do not seem to have had a general and lasting influence on American Swedish, modulo some individual variation. Contrary to Swedish, no official standard for spoken Norwegian exists. It is generally assumed that the dialects have survived to a much higher extent in Norway than in Sweden, even up to the present day. The emigrants, who often came from rural Norway, therefore brought with them their dialects from home. Johannessen \& Laake (to appear) show that a common dialect has developed in the American Midwest, based on the rural dialects in the Eastern valleys of Norway. In both Heritage Norwegian and Heritage Swedish, then, we can observe dialect leveling towards a dominant dialect or standard, and we therefore do not expect syntactic features that are restricted to some small, conservative dialect area (e.g. Övdalian, cf. section 3.2 below), to affect the development in Heritage Scandinavian.

As shown by e.g. Haugen (1953), Hasselmo (1974), Hjelde (1996a,b), Johannessen \& Laake (2011, 2012b, to appear) and Larsson et al. (2012, to appear), Heritage Scandinavian 
has several features that are due to borrowing from English. As expected, this is particularly clear in the lexicon. In (2a) we see a prepositional phrase borrowed into Heritage Norwegian, and in (2b) the preposition för 'for' has replaced the original European Swedish preposition $i$ 'in' in durative adverbials.

(2)
a. hå va re di gjorde during recess? (Heritage Norwegian)
what was it you did during recess [Eur.Norw.: i friminuttet]
'What were you doing during recess?'
(Eunice, 3rg gen, b. 1926 in Sunburg, MN; from Johannessen \& Laake 2012:370)
b. pappa hade gikt för många år innan han dog (Heritage Swedish)
father had gout for many years before he died [Eur. Swed.: i]
'Father had gout for many years before he died.'
(Fru Hansson, 1st gen., *1893 in Resele, Ångermanland recorded by Folke
Hedblom, 113B_m; from Larsson et al. to appear)

Both koineization processes and direct transfer from English can be noted already in early emigrant Scandinavian, and it is typical for speakers that have Norwegian or Swedish as their primary language and still use it in a variety of different contexts (and who might even speak little or almost no English). More fundamental changes in the grammar of Heritage Scandinavian are in a different way tied to the bilingualism of the speakers.

\subsection{Bilingualism: acquisition and attrition}

Work on bilingualism argue that bilingual speakers represent their languages as separate systems (se e.g. De Houwer 1990), but there is sometimes also evidence for transfer, perhaps particularly when the languages show structural overlap at the onset, but also depending on 
grammatical domain (see e.g. Argyri \& Sorace 2007, Sorace \& Serratice 2009 and references cited there). For instance, Argyri \& Sorace (2007) report that English-Greek bilinguals show transfer from English in the placement of subjects: in L1 Greek preverbal subjects are possible in some contexts, but in English-dominant Greek speakers, preverbal they are overextended to what-embedded interrogatives, arguably due to structural overlap with English. One difficulty in many studies of bilinguals is that it can be hard to distinguish variation in production that is due to processing factors, and variation that is due to differences in grammatical representation (cf. e.g. Montrul et al. 2008).

It is well known that there is often considerable intra-speaker variation among bilingual speakers, and that this cannot be accounted for exclusively in terms of age and order of acquisition. However, two main sources for grammatical variation in heritage grammars should be distinguished. Firstly, the heritage language might be gradually forgotten when it is not used (Seliger \& Vago 1991, Polinsky 1995, 2006, 2008, Sorace 2004, Tsimpli et al. 2004, Montrul 2005, 2008 inter alia). In the following, we refer to this process as attrition. Previous work on attrition has shown that it most clearly affects linguistic processing and lexical retrieval, and morphology, and that attrited speakers are typically sensitive to situation and type of task in a different way than other speakers. There are individual speakers of Heritage Scandinavian who have not used their L1 in 30 or more years, who have clear difficulties in their production, and who show changes in e.g. nominal inflection (see Johannessen to appear, cf. also Håkansson 1995). Other speakers have maintained their L1 and show few signs of attrition. Examples of attrition are illustrated in Section 4.1.

A second source of variation lies in the acquisitional process, and this is perhaps where heritage speakers can be most clearly distinguished from L2 speakers. Heritage Scandinavian speakers have acquired a Scandinavian language in a naturalistic setting, and from birth. Most of the speakers in our study are not simultaneous bilinguals but started learning English in 
connection to their school start, at the age of 5 or 6 (but this often depends on whether they have older siblings or not). After that age, English quickly becomes their primary language. It is generally assumed that there is a critical period for native-like acquisition (see Hyltenstam \& Abrahamsson 2003 and references cited there), and as shown by e.g. Montrul (2008) heritage speakers often have advantages over L2 learners. This appears to be particularly evident in grammaticality judgments and directed elicitations (rather than in spontaneous production). However, heritage speakers also typically get less and possibly more inconsistent input than ordinary L1 learners (since the older generation are typically also bilingual speakers, and since the heritage language is spoken in a limited set of contexts), and the acquisitional process might be interrupted before a target-like grammar is attained. Incomplete acquisition is sometimes referred to as fossilized L1 development.

Both incomplete acquisition and attrition can sometimes have the same result, at least superficially and with respect to linguistic production, and it can clearly be difficult to empirically separate the two in individual speakers. In fact, it seems reasonable to assume that features that are not fully acquired are more easily affected in language loss than features that have been completely acquired (and where there is no initial variation). Despite this, we want to argue that the theoretical distinction between attrition and incomplete acquisition should be maintained. Given previous work, we expect that if changes in verb placement in the heritage speakers are due to attrition, the change will be either towards a simpler system (in some sense) or a system more similar to English. We also expect changes in production to relate to processing difficulties rather than to variations in grammatical representation. If changes in word order on the other hand depend on incomplete acquisition, we expect heritage speakers to behave like young monolingual children.

Putnam \& Sánchez (ms.) challenge this dichotomy between attrition and incomplete acquisition in a model they lay out for heritage languages, which is based on the processing of 
input in bilingual speakers. They assume that the more frequent exposure to the socially dominant L2 influence the activation of the L1 lexicon and its functional, semantic and phonological features. They see this influence in terms of transfer or reassembling functional features from L2 to the semantic and phonological part of L1. It seems to us that it is a model of attrition rather than of acquisition and it predicts that heritage speakers that do not use their L1 gradually change their L1-grammar to be more L2-like. In the following the distinction between the attrition and incomplete acquisition will be crucial, and we will see changes that are not in the direction of L2. As we will see, acquisition in (L1) Heritage Scandinavian appears to be very similar to the acquisition of European Scandinavian, and with respect to verb placement there is no obvious transfer from the L2. As far as we can see, Putnam \& Sánchez's model cannot account for our observations. (Nothing excludes that processing factors are relevant in both, or that both is at play in the individual speaker.)

In the following, we show how the distinction between attrition and incomplete acquisition accounts for the different patterns of variation and change in verb placement in main and embedded clauses in Heritage Scandinavian. We focus in particular on changes in embedded word order, which we argue are due to incomplete acquisition. The next section gives an overview of verb placement in the language of the Scandinavians who immigrated to America, and section 4 is concerned with verb placement in Present-Day Heritage Scandinavian. We return to the questions of attrition and acquisition in Section 5 below.

\section{Verb placement in Mainland Scandinavian and Emigrant Scandinavian}

The Mainland Scandinavian languages are V2-languages, with an asymmetry between main clauses (which are V2) and embedded clauses (which have the verb in situ). There is however 
some variation in both clause types, and this might be important for the study of changes in Heritage Scandinavian. In the following, we therefore briefly review the variation in verb placement to give a baseline for the study of Heritage Scandinavian in section 4 . We know little about the parents of all our Heritage Scandinavian informants, so Polinsky's (2008:41) definition of baseline ("the language that s/he was exposed to as a child") is not directly applicable. Here, we take the language used by the first generation emigrants (the ancestors of the heritage speakers), to be the relevant baseline language. As we will see, we can assume that Emigrant Scandinavian is identical to European Scandinavian in the relevant respects, and we therefore begin with an overview of verb placement in European Scandinavian main clauses (section 3.1) and embedded clauses (3.2). In section 3.3, we turn to Emigrant Scandinavian.

\subsection{Main clauses in Mainland Scandinavian}

As noted, the Scandinavian languages are all verb second (V2) languages. In declarative main clauses, the finite verb (whether auxiliary or main verb) therefore immediately follows the first constituent, whether it is a subject, an adverbial or some other fronted phrase; cf. (3a) and (3b). Also wh-questions have the verb in second position (disregarding for the moment some Norwegian dialects); see (4a) and (4b). ${ }^{1}$

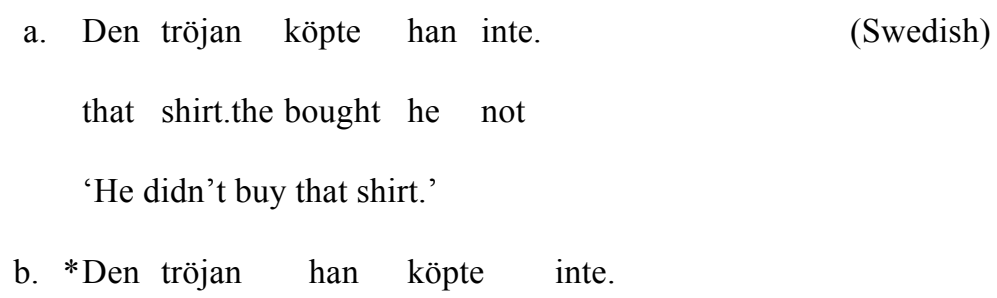

\footnotetext{
${ }^{1}$ Forms like tröjan 'shirt + definite suffix' are glossed as 'shirt.the' throughout.
} 
that the.shirt he bought not

(4)
a. Vad köpte han?
what bought he
'What did he buy?'
b. *Vad han köpte?
what he bought

(Swedish)

Following e.g. Rizzi (1997) and Westergaard \& Vangsnes (2005) and others, we will assume that the verb in main clauses spells out a head in the C-domain that determines clause type, and that the composition and properties of the C-domain can vary depending on clause type. However, for the present purposes the simplified structures in (5), where $\mathrm{C}, \mathrm{T}$ and $\mathrm{V}$ are used to cover a combination of heads, will suffice (lower copies are marked with strikethrough). We will assume that in V2-contexts, the verb is in a position in C, and that V2 involves V-to$\mathrm{C}$ movement. We moreover assume that the verb is always in $\mathrm{C}$ in main clause declaratives, also in subject-initial declaratives (which are in principle compatible with an analysis where the verb is in a lower position). ${ }^{2}$

\author{
(5) a. [CP [Den tröjan] köpte $\left[\mathrm{TP}\right.$ han këpte $\left[{ }_{\mathrm{NegP}}\right.$ inte $\mathrm{Neg}^{\mathrm{O}}[\mathrm{vP}$ han këpte \\ 'He didn't buy that shirt.' (= 3a) \\ b. [CP vad köpte [TP han këpte [vP han këpte \\ 'What did he buy?' (=4a)
}

There is not much variation in verb placement in Mainland Scandinavian main clauses, but we do find variation in Norwegian constituent questions. Like declaratives, constituent questions have $\mathrm{V}$-to-C movement in the standard Mainland Scandinavian languages, but most

\footnotetext{
${ }^{2}$ There is some variation in sentences with the adverb kanske 'maybe' in Scandinavian (see e.g. Andréasson 2002). Since this variation is quite restricted, and not relevant in the comparison with Heritage Scandinavian, it is disregarded in the following.
} 
dialects across Norway in addition have an alternative type of constituent question word order, in which both the wh-word and the subject are placed before the verb, and the finite verb remains in situ, and hence follows negation and other sentence adverbs. In (6a) the standard Mainland Scandinavian V2 word order is shown, and (6b) has the Norwegian dialectal non-V2. This variation has been widely studied; see Vangsnes (2005), Westergaard and Vangsnes (2006), Westergaard (2009), or Bentzen (2013) for a brief overview.

(6)
a. kor bor du?
(Norwegian)
where live you
b. kor $\mathrm{du}$ bor?
(Northern Norwegian)
where you live
'Where do you live?'

The word order variation in constituent questions is dialectal, and hence exists at a group level. As we will see in section 4, we find the same variation in constituent questions in Heritage Scandinavian. However, in addition we find variation in verb placement also in declarative main clauses in individual speakers, and especially in less proficient speakers.

\subsection{Embedded word order}

Embedded clauses typically do not express illocutionary force, and they are often assumed to have a more restricted C-domain (which presumably still varies depending on clause type). Unlike direct questions, embedded questions do for instance not express interrogative force, and the interrogative head that triggers V2 in the main question can be assumed to be missing from the structure of the embedded question (see e.g. Westergaard 2006, Westergaard \& 
Bentzen 2007 and references cited there). In other words, embedded clauses do not generally have V-to-C movement. Since European Scandinavian does not have V-to-T movement, the finite verb follows both the subject and sentence adverbs in embedded clauses; see the relative clause in (7) and the embedded question in (8) (cf. among many others Holmberg \& Platzack 1995, Vikner 1995):
a. tröjan som han inte köpte
(Swedish)
shirt.the that he not bought
'the shirt that he didn't buy'
b. * tröjan som han köpte inte shirt that he bought not
... vad han inte köpte
(Swedish)
what he not bought
'what he didn't buy'
b. * ...vad han köpte inte
what he bought not

(8) a

However, it is important to distinguish between different kinds of embedded clauses. As discussed by Heycock (2006), Julien (2007, 2008, 2009), Wiklund et al. (2009) and many others, there is variation with respect to verb placement in certain types of that-clauses (depending on matrix predicate). In examples like (9), the embedded verb can optionally be placed before negation. (The brackets in (9) mark that the complementizer is optional.)

(9)

a. Jag tycker (att) den passarinte bra. (Swedish)
I think that it fits not well
'I don't think that it fits well.'
b. Jag tycker (att) den inte passar bra.
I think that it not fits well


Examples like (9a) are often analyzed as involving embedded V2, and as having the verb in a position in the C-domain. In examples like these, it is also possible to have topicalisation and verb-subject order:

$$
\begin{aligned}
& \text { Jag tycker verkligen (att) den boken ska du inte läsa. (Swedish) } \\
& \text { I think really that that book.the should you not read } \\
& \text { 'I really don't think that you should read that book.' }
\end{aligned}
$$

It is debated what the precise restrictions of embedded V2 are (see e.g Julien 2007, 2008, 2009 and Wiklund et al. 2009), but it is typically restricted to asserted or semi-factive thatclauses in (European) Norwegian and Swedish, but there is variation between speakers and dialects. Importantly, V-to-C movement is never obligatory in that-clauses in Norway and Sweden, but it is not infrequent in the spoken language. On the contrary, in the Norwegian part of the Nordic Dialect Corpus (Johannessen et al. 2009) half of the that-clauses (474/937, 50.6\%) have the order verb-negation (Bentzen 2013; cf. Julien 2008). (Cf. also Jensen \& Christensen 2011, who argue that embedded V2 is more common in Danish than has generally been assumed.)

V-to-C movement is not possible in relative clauses or embedded questions, and in these kinds of clauses the finite verb therefore never precedes the subject. ${ }^{3}$ With respect to V-to-T

\footnotetext{
$d a$ 'then':

(i) Denne problemstillingen, som er da den viktigste i dag, ... this problem which is then the important.SUP today 'This problem, which is, then, the most important today...'
}

${ }^{3}$ The authors have noticed that it is not uncommon for some people, especially in formal settings, as when they are being interviewed on the radio, to have $\mathrm{V}$-A order if the adverb is

We have also seen that some people, typically in a speech or monologue, use a full V2 order in embedded questions:

(ii) Vi må spørre oss hva er det viktigste målet? 
movement, on the other hand, there is some, restricted variation. In some dialects (e.g. Regional Northern Norwegian), the finite verb can precede a sentence adverb, but it never moves across negation (see Bentzen 2013). Only a couple of conservative dialects seem to allow V-to-T movement across negation. This is for instance the case in Övdalian, where Vto-T movement appears to be required in certain very restricted contexts (in clauses with a null subject; see Rosenkvist 2011). Verb movement is, however, generally not obligatory in Övdalian. ${ }^{4}$ In the following, we use the term V-to-T movement exclusively to refer to verb movement across negation, and we will not be concerned with the placement of verbs relative other types of adverbs. Since European Scandinavian (with the exception of dialects like Övdalian) does not have V-to-T movement, what we find in Heritage Scandinavian is unexpected, as we shall see in Section 4. First, we consider the language of the Scandinavian settlers.

\subsection{Emigrant language}

The language in Haugen's and Hedblom's recordings of Emigrant Scandinavian is identical to European Scandinavian in the relevant respects. The Scandinavian emigrants brought with them a language with $\mathrm{V}$-to-C movement in main clauses and certain that-clauses, and V-in-

we must ask ourselves what is the important.SUP goal

'We must ask ourselves what the most important goal is.'

Both these types of V2 in embedded questions are used in somewhat formal settings, and not relevant for our heritage speakers. It is also possible that they are rather new constructions. They will be ignored in the rest of the paper.

${ }^{4}$ Sandøy (2008:189) claims that verb movement is possible in many types of embedded clauses in the dialect of Romsdal. With one exception with somewhat unclear origin, the examples he gives are all that-clauses. In part of the Nordic Dialect Corpus from locations in Møre og Romsdal, we don't find any examples of relative clauses where the finite verb precedes negation. (The search included sentences with the relative complementizer som followed by ikke 'not', separated by up to five words.) Cf. also Bentzen 2013. 
situ in embedded clauses (and some interrogatives). Examples of declarative clauses with V2 are given in $(11 \mathrm{a}-\mathrm{b})$.

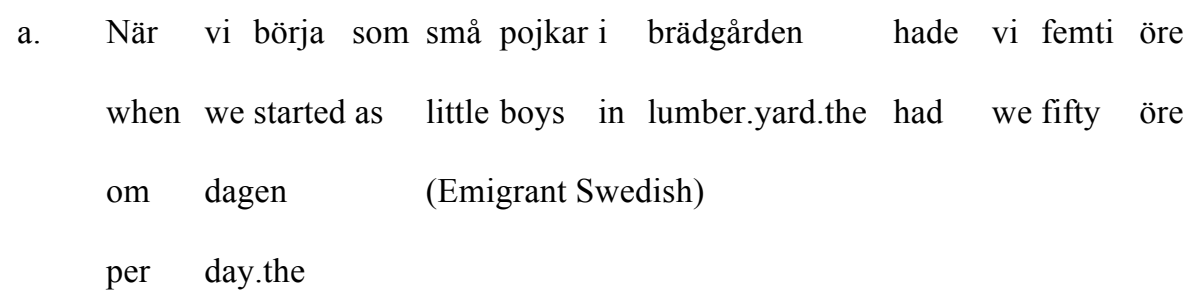

When we were little boys in the lumber yard we earnt fifty öre per day.'

(Mr Kallman, AM 79, born in Ångermanland, Sweden, in 1881, emigrated in 1903, recorded by Folke Hedblom)

b. Så fekk æg tikketen min ifrå Amerika (Emigrant Norwegian)

then got I ticket.the my from America

'Then I got my ticket from America'

(Jacob Seljestad, born in Hardanger, Norway, in 1866, emigrated in 1887, recorded by Einar Haugen in 1942, transcribed by Magne Oftedal)

It is hard to find examples of the dialectal non-V2 questions mentioned in 3.1 in Haugen's recordings, given that these are strict interviews where the informants answer questions rather than ask them. Since non-V2 questions are possible in many European Norwegian dialects and still occur in Heritage Norwegian (see below), we can assume that they were possible also in Emigrant Scandinavian.

In relative clauses, embedded questions and conditional clauses, the verb generally follows negation; examples are given in (12) and (13). Thus, there is no evidence for V-to-T movement in Emigrant Scandinavian.

a. om han inte var säker på att jag skulle komma den dagen if he not was sure on that I would come that day.the 'If he wasn't sure that I would come that day' 
(Mrs Friesendahl, Am 117A, born in Ångermanland, Sweden, in 1878, emigrated in 1898, recorded by Folke Hedblom)

b. jag kommer ihåg det gamla språket bara för

I remember the old language.the just because

att jag inte talar det

that I not speak it

'I remember the old language just because I don't speak it'

(Mr Hagstrom, AM 4A, born in Västergötland, Sweden, in 1890, emigrated in 1909, recorded by Folke Hedblom)

(13)

$$
\begin{aligned}
& \text { viss du inkje har riktig goe sement så dett an sund. } \\
& \text { if } \quad \text { you not have really good cement then falls he apart }
\end{aligned}
$$

'If you don't have really good cement, it falls apart'

(Jacob Seljestad, born in Hardanger, Norway, in 1866, emigrated in 1887, recorded by Einar Haugen in 1942, transcribed by Magne Oftedal)

As expected, there is some variation in certain that-clauses, which allow embedded V2. Examples with V2 are given in (14). (In (14a), the complementizer is omitted, which has no known effect syntactically or semantically; cf. (9) above.)

a. han tyckte han passa inte riktigt bra he thought he fit not really well 'He didn't think that it fit really well'

(Mrs Friesendahl, Am 117A, born in Ångermanland, Sweden, in 1878, emigrated in 1898, recorded by Folke Hedblom)

b. snøen va så dyp at me kunne ikkje gå the.snow was so deep that we could not walk

'The snow was so deep that we could not' 
As far as we can see, there is thus no reason to assume that Emigrant Scandinavian differs from European Scandinavian with respect to verb placement (cf. Hasselmo 1974 who comes to a similar conclusion). This means that we can use European Scandinavian as a baseline in the investigation of Heritage Scandinavian.

\subsection{Summary}

We have given a brief overview of word order in main and subordinate clauses in European and Emigrant Scandinavian, and concluded that the two are identical in the relevant respects. In main clauses, V2 is the standard, but interrogative main clauses can have non-V2 order in many Norwegian dialects. In subordinate clauses, V-in-situ (i.e. Neg-V) is the standard, except for certain semantically restricted that-clauses, which can also have V2 order. In a few European dialects (e.g. Övdalian), V-to-T (verb movement across negation) can be found in some subordinate clauses, but there is no evidence for V-to-T in Emigrant Scandinavian. Importantly, there is no reason to believe that dialects like Övdalian have influenced the development of Heritage Scandinavian (cf. section 2.1 above).

\section{Verb placement in Heritage Scandinavian}


In the previous section, we established a baseline with V2 in declarative main clauses and some that-clauses, and V-in-situ in most subordinate clauses and sometimes in interrogative main clauses, and, consequently, without V-to-T movement. There are no heritage speakers of dialects like Övdalian in this study, and as noted, there is no reason to assume that Övdalian has had any influence on Heritage Scandinavian. In other words, we do not expect V-to-T movement (i.e. the order where the verb precedes negation) in subordinate clauses.

In this section we will compare heritage data to our baseline. Section 4.1 gives an overview of the word order in main clauses, and 4.2 is concerned with verb placement in embedded clauses. $^{5}$

As noted in section 2.2 above, deviations from the baseline can have at least two possible sources. If Heritage Scandinavian shows a simplified syntax, this could be due attrition on an individual level (and/or possible be due to influence directly from English). Other changes could be due to incomplete acquisition, and in that case we predict that Heritage Scandinavian has a syntax that can also be found in European Scandinavian monolingual children. We will see below that both types of change can be found in Heritage Scandinavian. The explanations will be discussed further in section 5 .

\subsection{Main clauses}

Overall, Heritage Scandinavian is still a V2 language (see Eide \& Hjelde, this volume). Fluent heritage speakers generally have V2 in main clauses, as illustrated in (15):

a. Så stoppa han, så søkk trucken ned littegrann

\footnotetext{
${ }^{5}$ The data on embedded word order in Heritage Scandinavian have previosly been presented in Larsson \& Johannessen (to appear).
} 


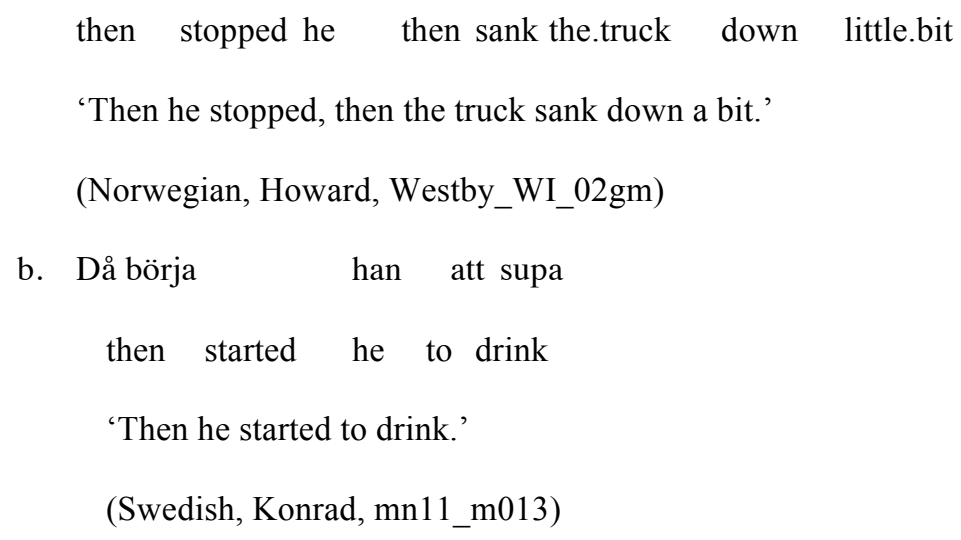

Heritage Norwegian speakers with the relevant dialect background have the verb in situ in some interrogative clauses, just as in varieties of European Scandinavian:

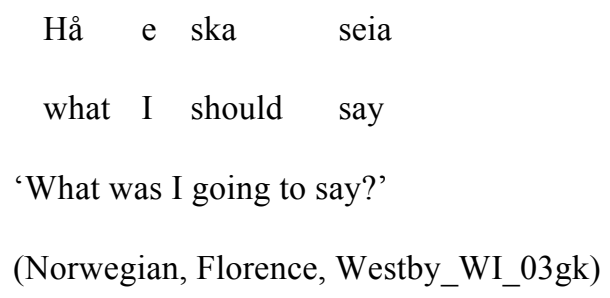

In these speakers, non-V2 order seems to be restricted to the same contexts as in the dialects (cf. Larsson \& Johannessen to appear). In other words, we cannot observe a general loss of Vto-C in Heritage Scandinavian.

However, it is clear that V2 is not completely stable across informants. In fact, heritage speakers that come across as less competent and confident sometimes have a main clause order not found in European or Emigrant Scandinavian, viz. non-V2 in declaratives (see Johannessen to appear, Eide \& Hjelde this volume). A couple of examples are given in (17). Non-V2 order is most common in topicalizations where the first constituent is long, and less common when the initial element is a short adverb (Johannessen to appear, Eide \& Hjelde, this volume). 
(17)

a. Surströmming jag skulle lika att pröva igen
fermented.herring I would like to try again
(Swedish, Arthur, mn11_m005)
b. Etter krigen kom, så mannen min og jeg fikk en apartment.
after the.war came so the.husband my and I got an apartment
After the war came, then my husband and I got an apartment
(Norwegian, Daisy, Chicago_IL_01gk)

The V2-violations in (17) are both produced by speakers who have not used their L1 regularly for many years, who speak slowly and with difficulty, and who show changes e.g. in morphology (Johannessen to appear, Larsson \& Johannessen to appear). We have the impression that these speakers also showed some improvement, and increasing confidence, during the interview, but this has to be investigated in detail.

It can be noted that while some speakers show V2-violations in topicalizations in main clauses, there seem to be few examples of main clauses where the verb follows negation; Eide \& Hjelde (this volume) find no such cases. This suggests that even when V-to-C movement starts to be lost, the verb is not left in situ, but in a position in the T-domain. In the Swedish recordings, there are a few examples where the finite verb follows negation in a declarative, even for speakers that still have V2 as the general rule and only show a few violations.

\subsection{Embedded clauses}

Considering verb placement in relative clauses and embedded questions, there is a striking difference between European Scandinavian and Heritage Scandinavian: in Heritage 
Scandinavian, the verb can precede negation, as in (18). In Emigrant Scandinavian, examples like these are unattested, and in European Scandinavian, they are ungrammatical.

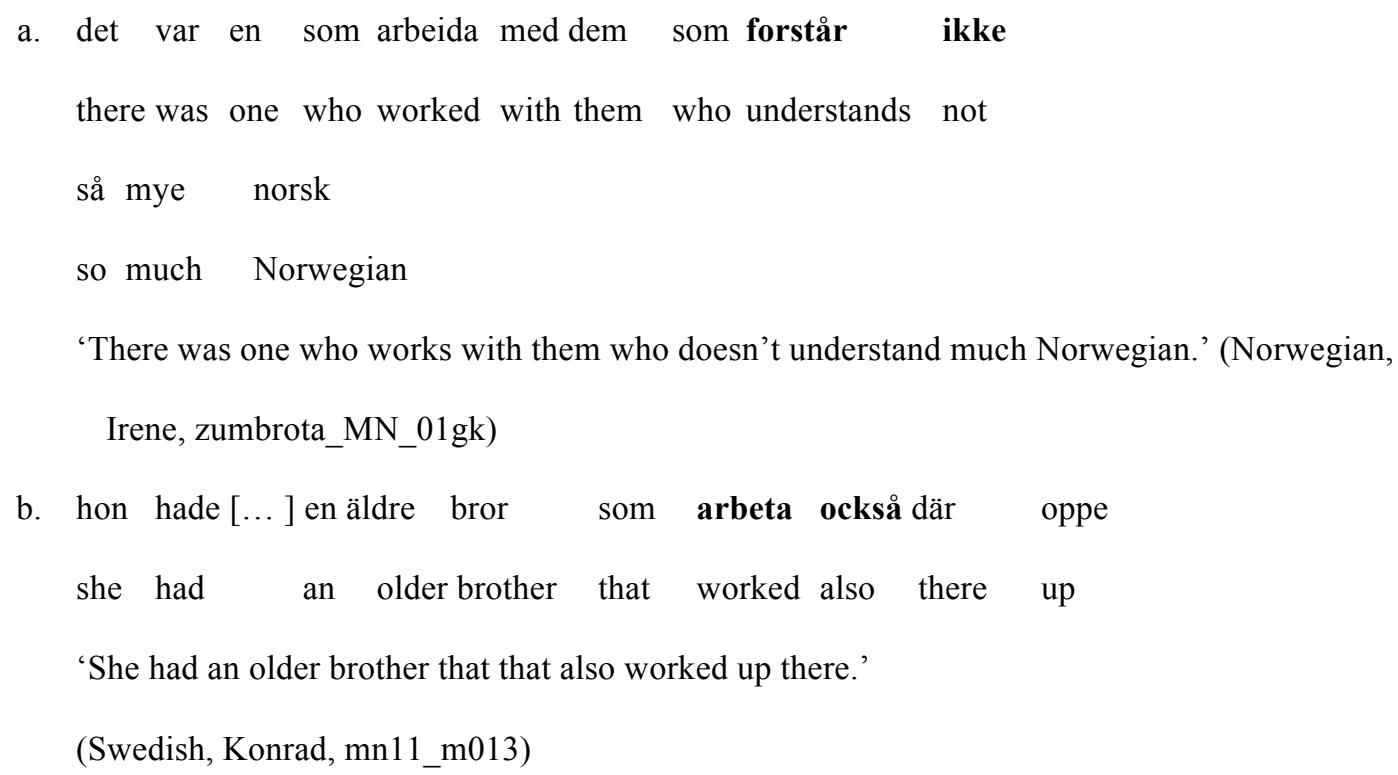

Unlike the cases of V2-violations in main clauses, which are restricted to certain speakers, examples with verb movement in embedded clauses are more widespread, also among heritage speakers that are fluent and show little or no evidence of attrition. We find the same patterns in both Heritage Norwegian and Heritage Swedish, and independently of the dialect background of the informants. According to Larsson \& Johannessen (to appear) around half of the cases have the order finite verb-negation; though the number of cases is small, the difference between Heritage Scandinavian and European Scandinavian is highly statistically significant $(\mathrm{p}<0.001$ w.r.t. that-clauses and $\mathrm{p}<0.03$ w.r.t. relative clauses). In a study of Heritage Norwegian, Taranrød (2011) found only 12 relative clauses that also included sentence adverbials; six had the order verb-negation and six had the baseline order negationverb.

Individual speakers alternate between the two orders. The Heritage Swedish speaker Konrad, for instance, produces 4 relevant examples, 2 of which have the order verb-negation 
and 2 with the order negation-verb. The following examples are produces by the same Heritage Norwegian speaker:

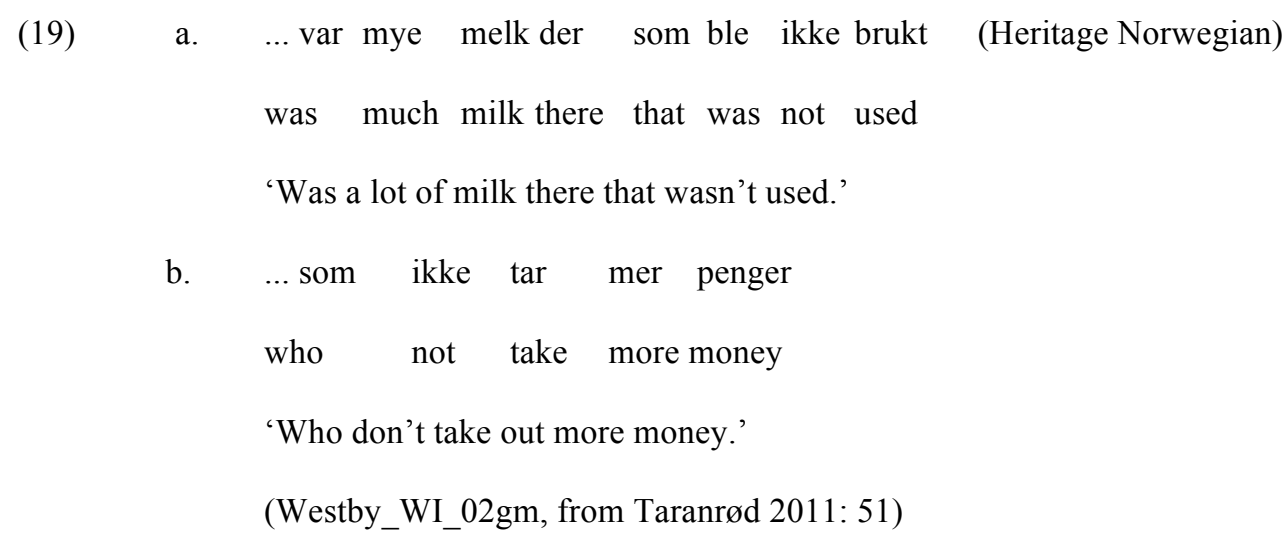

Here, the passive auxiliary precedes negation in (19a), while the main verb follows negation in (19b). We can, however, not immediately correlate the variation with a distinction between auxiliaries and main verbs. Other speakers produce the opposite pattern. There is for instance another speaker in Taranrød's study, from the same small town as the speaker in (19), who produces a relative clause with a finite form of vare 'be' following negation, and a relative with bruke 'use' preceding negation.

Now, let's consider that-clauses. As in European Scandinavian, that-clauses in Heritage Scandinavian sometimes show evidence of verb movement. In (20a), the verb remains below negation. In (20b) it has moved to a higher position; as we have seen, this order is a possibility also in European Scandinavian.

a. vi er lykkelige på den måten $[\ldots]$ at vi ikke bruker
we are lucky on the way.the that we not use
stav eller noe slikt
stick or something such
'We are lucky that we don't use staves or such things.'




(Norwegian, Elnor, coon_valley_WI_02gm)
b. jag visste att han skulle inte leva mycket längs
I knew that he would not live much longer
'I knew that he wouldn't live much longer'
(Swedish, Konrad, mn11_m013)

However, also in this case we can observe a deviation from the baseline: the frequency of the order verb-negation is considerably higher in Heritage Scandinavian than in European Scandinavian. In the recordings investigated by Larsson \& Johannessen (to appear) 15/16 (94 $\%)$ of the that-clauses with negation have verb movement; in European Norwegian, the corresponding frequency is considerably lower, as we saw in section 4.2 above (cf. also the data from Waldmann 2008 discussed in 5.2 below).

In other words, Heritage Scandinavian seems to have more general verb movement in embedded clauses than European Scandinavian, and unlike V-to-C movement in Heritage Scandinavian, verb movement across negation in Heritage Scandinavian appears to be possible independently of clause type. It should also be noted that while the finite verb can move across negation in embedded clauses in Heritage Scandinavian, it does not move across the subject, as in main clauses (or in some examples with embedded V2). In Heritage Scandinavian, the verb never precedes the subject in embedded questions; cf. the examples in (21) and (22) (and see Larsson \& Johannessen to appear for additional discussion).

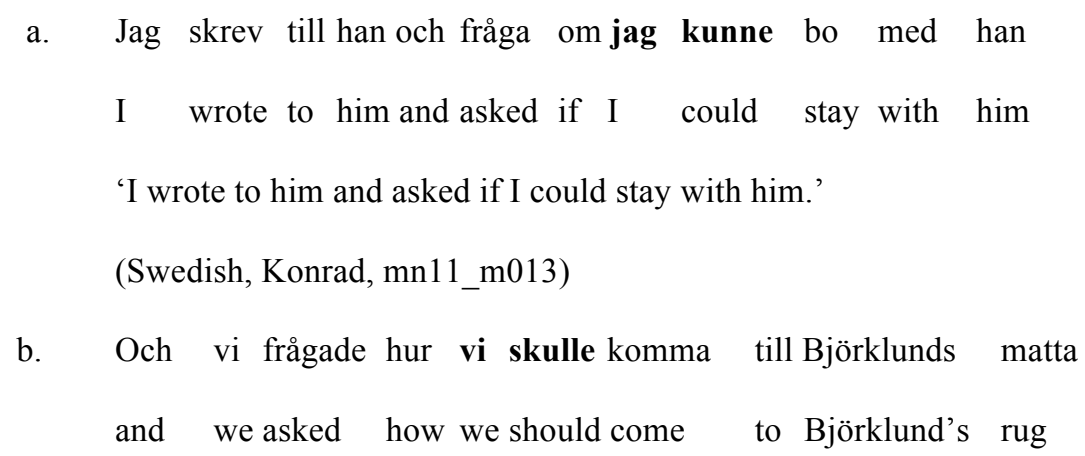


'And we asked how we could get to Björklund's rug.'

(Swedish, Theodor, mn11_m018)

$$
\begin{aligned}
& \text { vi kan figure ut messom hva de sier } \\
& \text { we can figure out about what they say } \\
& \text { 'We can figure out approximately what they say.' } \\
& \text { (Norwegian, Eleanor, coon_valley_WI_07gk) }
\end{aligned}
$$

The verb-adverb order in embedded clauses should therefore not be understood as a pure generalization of V2 from main clauses and certain that-clauses (see e.g. Heycock et al. 2012 for discussion). Instead, we conclude that the verb is in a lower position in embedded clauses than in V2-contexts, and we take it to be in a position in the T-domain. In other words, Heritage Norwegian and Swedish differ from European Norwegian and Swedish by having (optional) V-to-T movement. V-to-T movement accounts for the fact that verb-adverb order is more common in Heritage Scandinavian that-clauses than in European Scandinavian: in European Scandinavian, verb-adverb order is always due to V-to-C movement, whereas in Heritage Scandinavian it can also be a consequence of V-to-T movement.

\subsection{Summary: syntactic change in Heritage Scandinavian}

In this section, we have noted a couple of cases where Heritage Scandinavian differs from Mainland Scandinavian with respect to verb placement. In main clause declaratives, V2-order is still the general rule, just as in European Scandinavian. Some speakers show examples with non-V2, but these are generally less fluent speakers that show signs of attrition. Fluent speakers of Heritage Norwegian dialects that have non-V2 order in some types of constituent 
questions, show the same pattern as the European Norwegain speakers of the same dialects. In subordinate clauses, we find a more general change: unlike European Scandinavian, Heritage Scandinavian has verb movement across negation in all kinds of embedded clauses. We therefore conclude that Heritage Scandinavian has optional V-to-T movement, unlike European Scandinavian. V-to-T movement in Heritage Scandinavian appears to be independent of clause type, and it does not correlate with the fluency of the speakers. We contend that a change has taken place in the syntax of Heritage Scandinavian.

\section{Attrition, acquisition and verb placement}

In the previous sections, we could observe that verb placement in present-day Heritage Scandinavian sometimes deviates from the baseline, the language of the emigrants. However, as we have seen, the nature of these deviations is not the same in embedded clauses as in main clauses. In embedded clauses, we find intra-speaker variation between V-in-situ and V-to-T, whereas in main clauses we find a beginning loss of V-to-C (but possibly V-to-T) in a subgroup of the heritage speakers (but also intra-speaker variation in these speakers). In this section, we argue that the deviations have different sources: the V2-violations in main clauses found in some speakers are due to attrition, whereas the more widespread change in verb placement in embedded clauses is due to incomplete acquisition (cf. also Larsson \& Johannessen to appear).

\subsection{Verb placement in attrition: loss of $V$-to-C}


As shown by Eide \& Hjelde (this volume) and Johannessen \& Laake (to appear), Heritage Scandinavian is still overall a V2-language. Deviations from the V2-rule are, as we have seen, restricted to certain individuals, and particularly to individuals that show other signs of attrition. These speakers use simple sentences, and we typically do not find examples of embedded clauses with adverbs in their production. It is sometimes said that attrition affects morphology but not 'core syntax' (see e.g. Montrul 2008). If syntax is affected, change can possibly be expected to be L2-induced (cf. Putnam \& Sánchez ms.) and towards the dominant language (English). ${ }^{6}$ This could be argued to be the case when V2 is lost: Heritage Scandinavian loses general V-to-C movement in main clauses, since English is not a full V2language (but see below).

According to both Eide \& Hjelde (this volume) and Johannessen (to appear), V2-violations are particularly common after heavy fronted adverbials. Moreover, speakers can behave differently depending on situation. This suggests that these violations relate to processing difficulties, and that they should be understood as performance errors rather than as changes in the underlying grammatical system; this would be in line with previous work on attrition.

There are two important points to note. First, inter-speaker differences in verb placement in main clauses do not seem to correlate with differences in how the language was acquired (but, rather how it has been maintained). Second, speakers that produce main clause V2-violations do not seem to behave like monolingual children in Norway and Sweden. Movement of finite verbs to $\mathrm{C}$ is acquired rather early in monolingual children. According to Waldmann (2008:

\footnotetext{
${ }^{6} \mathrm{~A}$ reviewer asks if we see $\mathrm{L} 1$ attrition and L2 influence as the same or related phenomena. We believe that it is important to keep the two apart. For instance, we view lexical retrieval delays as a consequence of attrition, not of L2 influence. There can also be L2 influence on an L1 without attrition, perhaps particularly with regard to vocabulary (cf. section 2.1 above). While there does seem to be cases where attrition leads to change towards the dominant language (perhaps particularly when there is some overlap between the systems to begin with; see below and cf. Section 2.2 above), it is also possible for simplification not to be induced by L2. When English is L2 and a dominant language while a Scandinavian language is L1, influence by L2 and simplification of L1 can have the same effect, and the two factors can therefore sometimes be difficult to distinguish empirically.
} 
181), at least some Swedish children acquire productive V-to-C movement before the age of three. The child in Waldmann's study of four children that shows the slowest development has completely target-like behavior at the age of 3;6 (2008: 178). We therefore have no reason to expect that the heritage speakers that were monolingual in Norwegian or Swedish until the age of 5 or 6 would not have fully acquired V2. There is still ample evidence for V-to-C movement in Heritage Scandinavian, and nothing suggests that this was not the case also in the input that the heritage-speaking children received.

We conclude (with Eide \& Hjelde, this volume, and Johannessen, to appear) that V2violations in main clauses are due to attrition. It is possible that loss of V2 in attrition is partly due to influence from English, and it might be important that SV-order is common in both English and Scandinavian (i.e. that there is superficial structural overlap). However, it might also be the case that V-to-C movement, and the $\mathrm{C}$-domain in general, is particularly sensitive independently of what the primary language of the speaker might be, perhaps since it encodes properties that are relevant for the syntax-pragmatics interface (cf. e.g. Platzack 2001, Müller \& Hulk 2001). As far as we can see, it would be premature to attribute the loss of V2 in attrition solely to English influence.

As we have seen, the change in embedded word order is of a different kind. First, it is more widespread among the heritage speakers, and it does not appear to relate to how much the speaker uses the heritage language. Fluent speakers that do not otherwise show any clear signs of attrition (e.g. V2-violations, morphological change, or considerable lexical retrieval delays) have V-to-T movement. Recall also that even the attrited speakers in the study by Eide and Hjelde that are starting to loose V-to-C movement still do not seem to leave the verb in situ, but always place the verb before negation in main clauses. Thus, these speakers, too, appear to have (optional) V-to-T movement. 
Furthermore, the change in Heritage Scandinavian embedded clauses is not towards a simpler system, or a system more like English: verb movement is introduced into the grammar, not lost. Although English has verb movement in a restricted set of contexts, main verbs do not move to $\mathrm{T}$, but obligatorily follow negation and other sentence adverbs:
a. The man $\left\{{ }^{*}\right.$ works $\}$ actually $\{$ works $\}$ up there.
b. a man who $\left\{{ }^{*}\right.$ worked $\}$ actually $\{$ worked $\}$ up there

If word order in Heritage Scandinavian were affected by English word order, we would in other words rather expect absence of verb movement where European Scandinavian has verb movement. If it were due to attrition, we would at least expect it to correlate with the paucity of language use in the individual, and with other signs of attrition. In Larsson \& Johannessen (to appear), we conclude that V-to-T movement is an innovation in Heritage Scandinavian (and not inherited from dialects like Övdalian), but that it is not due to direct influence from English or to attrition. Instead, we argue that it is a consequence of incomplete acquisition.

\subsection{Incomplete acquisition in verb placement: $V$-to- $T$}

Given that V-to-T movement in Heritage Scandinavian is due to incomplete acquisition, we expect the heritage speakers to pattern with monolingual children in Scandinavia. This is what we find: with respect to embedded word order, Scandinavian heritage speakers behave like L1-learners in Norway and Sweden.

As shown by e.g. Håkansson \& Dooley Collberg (1994), Westergaard \& Bentzen (2007) and Waldmann (2008), European Norwegian and Swedish monolingual children have 
optional verb movement, just like heritage speakers. Examples are given in (24) (cf. Larsson \& Johannessen to appear). ${ }^{7}$

a. $\quad$ E skal bare gjøre sånn som du har aldri gjort før

I shall only do such that you have never done before

'I'm just gonna do something that you have never done before'

(Iver, 4;5.0, Northern No.; from Bentzen 2003:586)

b. då får ni säj bn dopp om ni höve inte m nån bäde

then can you say bn stop if you need not $m$ some boards

'Then you can say stop if you don't need any boards.'

(Harry 3:0.26, Swedish; from Waldmann 2008:229)

In Waldmann's (2008) study, Swedish children between the ages of 1;3-4;0 place the finite verb before a sentence adverbial in $40 \%(10 / 25)$ of the embedded clauses, disregarding thatclauses. In that-clauses, verb movement is more common: $79 \%(49 / 62)$ have the finite verb before the adverbial (2008: 223). In the input, the frequency of embedded V2 is considerably lower (2008: $141 \mathrm{f}$.), roughly $35 \%$ (partly depending on type of that-clause). In other words, monolingual children have verb movement in embedded clauses where it is not possible in the adult grammar, and they more frequently move the verb across the sentence adverbial in thatclauses, where also the adult grammar allows verb movement. Norwegian children show the same pattern. According to Westergaard \& Bentzen (2007) children between the age of approximately $1 ; 9-3 ; 3$, seem to prefer verb movement in embedded clauses over the order with the finite verb in situ, regardless of whether the target grammar allows verb movement or

\footnotetext{
${ }^{7}$ It has sometimes been suggested that Scandinavian children (unlike adults) treat auxiliaries and main verbs differently, and have a stronger tendency to place auxiliaries in the T-domain (see e.g. Håkansson \& Dooley Collberg 1994, Heycock et al. 2013). However, not all studies show the same pattern (cf. Waldmann 2008), and it seems that some, but not all, children distinguish auxiliaries from main verbs. This is what we would expect to find in Heritage Scandinavian, but at present we cannot see a clear pattern - the examples are simply too few. In a pilot study where we gave Heritage Norwegian speakers a translation task, some of them used V-neg order with the verb 'be', but neg-V order when the verb was 'buy'. However, it is possible that this is simply due to transfer from English (since the task involved translation), and this needs to be controlled for.
} 
not. Similar patterns have been found in Faroese: Faroese children have more V-to-T than do adult speakers (Heycock et al. 2013).

Though the numbers are generally small in the individual studies, the fact that data from monolingual (and bilingual) acquisition of Mainland Scandinavian and Faroese, and from Scandinavian heritage language, point in the same direction can hardly be disregarded. Moreover, data from different sources (spontaneous production, elicitiation) converge, and the pattern of verb placement is the same in monolingual children as in heritage speakers, despite the fact that the adult heritage speakers in many other ways differ considerably in their production (semantically, pragmatically, cognitively) from pre-school children. In other words, optional V-to-T movement appears to be a feature of incompletely acquired Scandinavian in general, even when verb agreement is missing (recall from Section 1 that agreement has been considered a factor in V-to-T movement), and contrary to what might be expected e.g. from economy considerations.

To conclude, the fact that Heritage Scandinavian patterns together with monolingual child language strongly suggest that incomplete acquisition is involved. This means that the Heritage Speakers have never fully acquired a grammar without V-to-T movement. Importantly, European Norwegian and Swedish L1-learners appear to retain a grammar with optional V-to-T movement for some time, and acquisition of embedded word order appears to take longer than has sometimes been assumed. All 4 children in Waldmann's (2008) study have both adverb-verb and non-target verb-adverb order in embedded clauses throughout the investigated period $(2 ; 3-4 ; 0)$. Westergaard \& Bentzen (2007: 285) show that even older children sometimes retain V-to-T movement. In their study, Iver $(5 ; 9.18)$ produces non-target verb-adverb order in 7 out of 8 embedded questions during an elicitation task. Results from Faroese show that the acquisition of embedded word order can be delayed even further. According to Heycock et al. (2013), children show rates of V-to-T both in acceptance and 
production, which up to the age of 7 exceeds the frequency in the input considerably. It seems likely that this delay relates to the fact that while Faroese adults have a strong preference for V-in-situ, a grammar with V-to-T is still marginally available (cf. Thráinsson 2003).

The frequency of embedded clauses with adverbs is considerably lower than e.g. the frequency of main clauses with subject-verb inversion (see Westergaard \& Bentzen 2007, Table 3, Waldmann 2008: 125), and in combination with the complexity of the structures this presumably leads to slower acquisition. In fact, the evidence for adverb-verb order (i.e. V-insitu) is even weaker in the input of the heritage speakers than for the monolingual European Norwegian and Swedish speakers - it is typical that heritage speakers receive less and more inconsistent input. In Heritage Scandinavian, relative clauses are in general more infrequent, and examples with adverbs are also considerably more infrequent than in European Scandinavian (see Karstadt 2003: 105, Taranrød 2011, Larsson \& Johannessen to appear). Taranrød (2011: 53) shows that relative clauses with adverbs are infrequent in both groups, but almost twice as frequent in European Norwegian as in Heritage Norwegian (an average of 0.9 against 0.5 per informant). If frequency affects the rate of acquisition (but not the acquisitional path), heritage speakers are thus expected to retain V-to-T movement longer than children in Norway and Sweden. Since English quickly becomes the strongest language when the heritage speakers start school, a grammar without V-to-T is never fully acquired, and these speakers therefore retain $\mathrm{V}$-to-T movement also as adults.

\section{Incomplete acquisition, variation and change}

In the preceding sections, we have observed changes in verb placement in Heritage Scandinavian. We have suggested that V2-violations found in individual speakers are most 
likely due to attrition. The more widespread change in embedded word order should, on the other hand, be understood as a case of incomplete acquisition - the pattern with variation between V-to-T and V-in-situ in embedded clauses is the same in child acquisition as in the heritage language. In other words, there seems to be reason to view (monolingual) language acquisition as a process that is not necessarily completed before school-start. Rather, some aspects of language acquisition can apparently be delayed further if the language learner is presented with insufficient or conflicting input. This immediately argues against the hypothesis of early parameter setting (Wexler 1999), at least for verb placement in Scandinavian. $^{8}$

We have, however, not addressed the questions why we find this variation in child and heritage language, how it should be accounted for, and how incomplete acquisition (of verb placement) should be understood theoretically. In the following, we raise some of the questions, leaving many important issues and a full discussion aside. Section 6.1 gives a brief discussion of the source of V-to-T movement in the acquisition of Scandinavian, based on previous work on acquisition of word order. Section 6.2 focuses on the problems of variation and change and the question of how incomplete acquisition should be understood.

\subsection{Cues for verb placement}

V-to-T movement in incomplete acquisition of Scandinavian can be assumed to be a consequence of the acquisition of V2 (e.g. Westergaard \& Bentzen 2007, cf. Heycock \& Wallenberg 2012, and Larsson \& Johannessen to appear). Since the Scandinavian languages

\footnotetext{
${ }^{8}$ This obviously does not mean that other aspects of grammar cannot be acquired early despite limited input. See Berwick et al. (2012) for a recent discussion of the poverty of the stimulus argument.
} 
are V2-languages, there is ample evidence for verb movement in main clauses. Whereas nonsubject initial main clauses with verb-subject order (25a) are unambiguous cues for a grammar with V-to-C, subject-initial declaratives with verb-adverb order (25b) are also compatible with a grammar with V-to-T and without V-to-C. That-clauses with embedded V2 and subject-verb order are also compatible with either V-to-T or V-to-C.

a. Den boken läser hon inte. (Swedish, V-to-C)
that the.book reads she not
'She doesn't read that book.'
b. Hon läser inte den boken.
she reads not that the.book
'She doesn't read that book.'

It has been suggested that children assume V-to-T movement at an early stage in the acquisition of V2, based on examples like (25b) in their input (Westergaard \& Bentzen 2007). $\mathrm{V}$-to-C movement is less economical and therefore a dispreferred choice, but based on input like (25a) (i.e. verb-subject order in non-subject initial declaratives, $w h$-questions and polarity questions) children will at a second stage move the verb to $\mathrm{C}$ (depending on clause-type), yielding a grammar with both V-to-T movement and V-to-C movement. This would be the grammar of young children and heritage speakers.

On this account, acquisition is cue-based, it proceeds through stages, and parameters can be set and reset (cf. Westergaard \& Bentzen 2007: 299). Specifically, children will have to reset the V-to-T parameter, so to speak, in order to acquire the target grammar with V-to-C but without V-to-T. For this, they need evidence for absence of V-to-T movement in their input. In a cue-based account of the acquisition of embedded word order with the verb in situ, input with the order adverb-V (but perhaps with distinctions between different types of 
adverbs) leads the child to formulate a target-like piece of syntactic structure, using pieces (features, categories) and principles provided (partly) by UG. (Cf. e.g. Lightfoot 1999, Lightfoot \& Westergaard 2007, Westergaard 2009, 2013 on cue-based acquisition and microcues.)

As we have seen, unambiguous evidence for $\mathrm{V}$-in-situ is infrequent in the input, and even more infrequent in the input for the heritage speakers, and this might be a reason why the resetting of the V-to-T parameter can be delayed. We could more generally hypothesise that relearning (resetting of parameters) is particularly sensitive to input frequency, and that it is more easily delayed than the initial parameter setting. As usual, negative evidence is presumably not directly available to the language learner, so the V-to-T parameter must be reset on the basis of positive evidence for $\mathrm{V}$-in-situ, and on the assumption that the two options (+/-V-to-T) are mutually exclusive.

Empirically, we can identify a stage in the acquisition of (Heritage or European) Scandinavian where V2 is not fully acquired, and where the language learner produces main clauses with XSV-order and sometimes also Neg-V-order (cf. Waldmann 2008: 178, table 6.14), then a stage with V2 in main clauses and V-Neg in embedded clauses (as in Heritage Scandinavian), and finally a stage with V-to-C but without V-to-T. However, we cannot simply say that the child proceeds from a grammar without verb movement, to a grammar with V-to-T, a grammar with V-to-T and V-to-C and finally to a grammar with V-to-C but without V-to-T. Throughout the acquisition process, both children and heritage speakers show intra-individual variation between $\mathrm{V}$-in-situ and V-to-T, which is not found in the adult grammar (cf. Roeper 1999: 170, who contends that the variability in child language argues against a coherent concept of stage). The variability is sometimes in and of itself taken as evidence for incomplete acquisition. 


\subsection{Incomplete acquisition, variation and change}

One common way of accounting for syntactic variation is to assume that speakers have more than one grammar (Kroch 1989, Roeper 1999, Yang 2002 inter alia). This would mean that the heritage speakers in our study that alternate between V-to-T and V-in-situ have two competing grammars: one with V-to-T movement, and one without.

Yang $(2002,2010)$ develops a variational model for the process of acquisition, where the child is taken to select between different grammars provided by UG. The more compatible a grammar is with the input, the more it will be favoured. Grammars that are less consistent with the input will consequently be gradually more and more disfavoured. Importantly, the notion grammar should here be understood as something different from what we usually mean when talk about two language systems (like English and Heritage Scandinavian) in the individual, since these grammars can differ minimally from each other - here, the features of $\mathrm{T}$ might be the only difference - and since nothing suggests that these grammars are represented as separate systems in the individual. Roeper (1999) hypothesises that a lexical class with rules that are incompatible with another class constitutes a separate grammar.

In the present context, we could view grammar competition as (unstable) competition between two functional items that only differ with respect to an EPP feature (assuming for convenience that EPP triggers movement). Rather than assuming that children choose from a pool of ready-made grammars, we assume (in line with current minimalist work) that an important task in acquisition is to assemble features into lexical items (cf. the cue-based account above). One possibility, then, is that evidence for verb movement in the input makes the child posit a T with an EPP feature. Variability is a consequence of the availability of a T without EPP, which we could assume comes for free (or is initially assumed). In any case, 
variation between two mutually exclusive alternatives can be modelled as competition. The assumption (not uncontested) would be that elements that are mutually exclusive in adult grammar, are mutually exclusive and compete in child language, too.

The question now is what is meant by (in)complete acquisition. For Yang (2000: 234) complete acquisition means that children conclusively settle on a single target language. Incomplete acquisition, on the other hand, means that more than one grammar (here, more than one T) is still available (but presumably, the adult (heritage) speakers no longer evaluates the input relative to the available grammars). On this view, any case of remaining variability in the adult grammar could be viewed as incomplete acquisition - at least when there is reason to assume that the alternating forms are mutually exclusive, and when the variation is diachronically unstable. ${ }^{9}$

In the present context, it seems empirically motivated to view incomplete acquisition in terms of maintained but unstable variability. We know from the history of Scandinavian that variation between V-to-T and V-in-situ is historically unstable (see Heycock \& Wallenberg 2012 for recent discussion), and in European Scandinavian V-in-situ is the only option (in the absence of V-to-C). This does obviously not automatically mean that all cases of incomplete acquisition should be viewed in this way. For instance, Westergaard (2013) argues that children gradually build up their grammars incrementally, and that they do not immediately extend a generalization to a major category. In this way, she accounts for the successful acquisition of fine-grained, information structural distinctions in syntax. On this view, incomplete acquistion would mean that the speaker has not made the generalization from a

\footnotetext{
${ }^{9}$ It has been suggested that there are cases of true optionality within a single, underspecified grammar (see e.g. Adger 2006, Biberauer \& Richards 2006, Richards 2008). These cases are however assumed to be examples of stable variation. Though variation between $\mathrm{V}$-in-situ and V-to-T can survive for generations, it is historically unstable, and V-in-situ eventually becomes the only possibility. Regardless of whether we assume optionality within a grammar or competition between systems, we need to account for the fact that some speakers show variation, whereas other speakers apparently do not.
} 
subcategory to a major category. It might be possible to extend or adapt this view to the case at hand, if we more generally assume that children in the acquisition process evaluate (and reevaluate) the analysis of the input, and continually modifies the assembly of features into lexical items and grammatical (sub-)categories - but at some point the previously posited $\mathrm{T}_{\mathrm{EPP}}$ must in any case be discarded from the child's grammar.

Given that children are highly competent language learners, any case of incomplete acquisition calls for explanation (cf. e.g. Yang 2000: 237). In the case of Heritage Scandinavian, explanations are not hard to find. The heritage speakers in the present study have had a more limited input of Scandinavian than European children, and they also live in a society where Scandinavian is only used in a very restricted set of contexts, and where it is for instance never used as an official or written language. These speakers, who we argue have acquired their L1 incompletely, have not transferred the language to the next generation with very few exceptions the next generation of speakers have English as their only L1. In the case of the history of Scandinavian, where V-to-T is gradually lost, something additional has to be said to explain incomplete transmission of the language system from one generation to the next, over several generations (cf. Heycock \& Wallenberg 2012, Heycock et al. 2012). ${ }^{10}$ Importantly, while incomplete acquisition can account for embedded word order changes in heritage speakers, it can hardly be extended to all cases of variation and change. (In fact, we have argued that there are other types of change even in Heritage Scandinavian; cf. section

\section{1 and section 5.1.)}

Incomplete acquisition thus requires further explanation in terms of input change and social factors. Also the notion of complete acquisition raises questions, e.g. why $\mathrm{T}_{\mathrm{EPP}}$ is discarded in the acquisition of European Scandinavian, despite the absence of negative input.

\footnotetext{
${ }^{10}$ It seems highly plausible that the change in embedded word order in European Scandinavian is tied to other changes in the linguistic system, e.g. changes in morphology and the requirements for overt subjects (see Falk 1993), and/or in the shift from OV-order to VO (Magnusson Petzell 2011).
} 
As far as we can see, the problem of how the child goes from variability to a categorical system has not been completely resolved within the variational model either (cf. Roeper 1999: 182: "These questions ... remain deeply puzzling."). It is not clear what is it that makes a grammar fall out of use and what it means for a child to 'finally settle on the target grammar' - particularly since individual speakers maintain more than one grammar throughout their lives. For instance, even if we view variation between V-to-T and V-in-situ as unstable competition, it is clear from the history of Scandinavian that the variation can persist in individual speakers and be transferred from one generation to the next (with shifts in the distribution of the alternants).

Roeper suggests that there might be social reasons (understood in a wide sense) for the abandonment of a grammar: "the English-speaking child abandons G2 (no Agreement), which is socially seen as a pre-school grammar as it moves into school and towards adulthood" (1999: 171). Here, we have not explicitly discussed the social aspects of word order acquisition, and we clearly do not want to attach social meaning directly to a functional item like T (cf. Adger 2006). However, there are obviously important social factors specific to the acquisition of Heritage Scandinavian (and heritage languages more generally). The fact that embedded word order appears to be acquired earlier in Sweden than in Norway, and earlier in Norway than in the Faroe Islands, could for instance be argued to relate to the stronger linguistic norm in Sweden, and the Danish influence (and conflicting norms) on Faroese. Heritage Scandinavian speakers have little metalinguistic competence, and are generally unconscious of linguistic norms. Again, the issue is however not restricted to acquisition and change of embedded word order in Scandinavian, but is more general in studies of syntactic change. 


\section{Conclusion}

In this paper, we have argued that the theoretical distinction between attrition (language loss in the individual) and incomplete acquisition is important in the understanding of variation and change in heritage grammar - despite the fact that they can be empirically hard to distinguish, and can possibly be related in the individual cases. Specifically, we have suggested that while changes in verb placement (i.e. V2-violations) in main clauses in Heritage Scandinavian are due to attrition, the more widespread change in embedded word order, and the introduction of V-to-T movement, is due to incomplete acquisition.

In the case of V2-violations, processing factors might have something to say (as suggested by previous work on attrition), but the role of transfer from English remains unclear. With respect to embedded word order, we find clear parallels with language acquisition in European Scandinavian. In the case of incomplete acquisition, it is clear that the heritage speaking child has acquired a grammatical system that is different from both the Scandinavian grammar of the previous generation, and from the English grammar, and which produces a word order (with V-to-T movement) that cannot be found in the input. A model of change in heritage grammar like that suggested by Putnam \& Sánchez (ms.), or any account that assumes transfer from L2 to be the main source of change in heritage grammar, can therefore not account for the word order in Heritage Scandinavian. We can, however, also see that the input (of Scandinavian) is important - the paucity of evidence for a V-in-situ grammar in the input leads to delayed learning, and in the case of the heritage speakers, to incomplete acquisition.

The question of how incomplete acquisition should be understood theoretically is still largely open. It clearly depends on our general theory of grammar and language acquisition, but it also seems to be the case that what is meant by incomplete acquisition also depends on 
the particular grammatical domain, and on how the acquisition of a particular aspect of grammar relates to other parts of the linguistic system (in the particular language to be acquired). It is for instance not evident that all aspects of grammar acquisition are equally sensitive to input frequency as embedded word order (in Scandinavian). In the present context, incomplete acquisition of verb placement in embedded clauses is likely to be tied to the acquisition of V2. The incompletely acquired $\operatorname{grammar}(\mathrm{s})$ is(/are) characterized by showing variability not present in the baseline language, and particularly, by allowing both Vto-T and V-in-situ.

\section{References}

Adger, David. Combinatorial Variability. Journal of Linguistics 42, 503-530.

Andréasson, Maia. 2002. Kanske - en vilde i satsanalysschemat $\square$. (Meddelanden från Institutionen för svenska språket 41.) Gothenburg: Institutionen för svenska språket, Gothenburg University.

Andréasson, Maia, Ida Larsson, Benjamin Lyngfelt, Jenny Nilsson \& Sofia Tingsell. 2013. I jakt på amerikasvenskan. In Svenskans beskrivning 32, Björn Bihl, Jessica Eriksson, Peter Andersson and Lena Lötmarker (eds.). Karlstad.

Argyri, Efrosyni \& Antonella Sorace. 2007. Crosslinguistic influence and language dominance in older bilingual children. Bilingualism: Language and Cognition 10(1): 79-99.

Bentzen, Kristine. 2003. V-to-I movement in the absence of morphological cues: Evidence from adult and child Northern Norwegian. Nordlyd: Proceedings from the $19^{\text {th }}$ Scandinavian Conference of Linguistics 31: 573-588. 
Bentzen, Kristine, 2007. The degree of verb movement in embedded clauses in three varieties of Norwegian. Nordlyd 34: 127-146.

Bentzen, Kristine. 2013. Verb placement. In The Nordic Atlas of Language Structures Online (NALS). http://tekstlab.uio.no/nals\#/chapter/9.

Berwick, Robert C., Noam Chomsky, and Massimo Piattelli-Palmarini. 2012. Poverty of the stimulus revisited. In Rich Languages from Poor Inputs, eds. Massimo PiattelliPalmarini and Robert C. Berwick

Biberauer, Theresa \& Marc Richards. 2006. True Optionality: When the grammar doesn't mind. In Minimalist Essays, ed. Cedric Boeckx. Amsterdam: Benjamins.

Boas, Hans C. 2009. The Life and Death of Texas German. Durham: Duke University Press. Bobaljik, Jonathan. 2002. Realizing Germanic Inflection: Why morphology doesn't drive syntax. Journal of Comparative Germanic Linguistics 6.2: 78-102.

De Houwer, Annick. 1990. The acquisition of two languages from birth: A case study. Cambridge: Cambridge University Press.

Eide, Kristin Melum \& Arnstein Hjelde. This volume. V2 and morphological paradigms in Norwegian varieties spoken in the American Midwest.

Falk, Cecilia. 1993. Non-Referential Subjects in the History of Swedish. Diss. Lund: Institutionen för nordiska språk.

Hasselmo, Nils, 1974. Amerikasvenska. En bok om språkutvecklingen i Svensk-Amerika. Lund: Esselte stadium.

Haugen, Einar. 1969 [1953]. The Norwegian Language in America. Philadelphia.

Heycock, Caroline. 2006. Embedded root phenomena. In The Blackwell Companion to Syntax, vol. II, eds. Martin Everaert and Henk van Riemsdijk, 174-209. Oxford: Blackwell. 
Heycock, Caroline, Antonella Sorace, Zakaris Svabo Hansen, Frances Wilson. 2012.

Defecting the late stages of syntactic change: the loss of V-to-T in Faroese. Language 88: $558-600$

Heycock, Caroline, Antonella Sorace, Zakaris Svabo Hansen \& Frances Wilson. 2013. Acquisition in Variation (and Vice Versa): V-to-T in Faroese Children. Language Acquisition 20(1): 5-22.

Heycock, Caroline \& Joel Wallenberg. 2012. Explaining the loss of verb movement: How embedded V2 and V-in-situ conspired against V-to-T. Ms. University of Edinburgh \& Newcastle University.

Hjelde, Arnstein. 1996a. The gender of English nouns used in American Norwegian. In Language Contact across the North Atlantic, eds. Ureland og Clarkson, 297-312. Tübingen: Max Niemeyer Verlag.

Hjelde, Arnstein. 1996b. Some phonological changes in a Norwegian dialect in America. In Language Contact across the North Atlantic, eds. Ureland og Clarkson. Tübingen: Max Niemeyer Verlag.

Hjelde, Arnstein. To appear. Changes in a Norwegian dialect in America. In Johannessen and Salmons (eds.).

Holmberg, Anders \& Christer Platzack. 1995. The Role of Inflection in Scandinavian Syntax. New York \& Oxford: Oxford University Press.

Hyltenstam, K. \& N. Abrahamsson. 2003. 'Maturational constraints in SLA'. In The handbook of second language acquisition, eds. C. J. Doughty \& M. H. Long, 539-588. Oxford: Blackwell,

Håkansson, Gisela \& Sheila Dooley Collberg. 1994. The preference for Modal + Neg: an L2 perspective applied to Swedish L1 children. Second Language Research 10:95-124. 
Håkansson, Gisela. 1995. Syntax and morphology in language attrition: a study of five bilingual expatriate Swedes. International Journal of Applied Linguistics 5:153-171.

Håkansson, David. 2013. A variationist approach to syntactic change: The case of subordinate clause word order in the history of Swedish. In Language Variation - European Perspectives IV, eds. Peter Auer, Javier Caro Reina \& Göz Kaufmann, 129-143. Amsterdam: John Benjamins Publishing Company.

Jensen, Torben Juel \& Christensen, Tanya Karoli, 2011. V2 word order in subordinate clauses in spoken Danish. Main/embedded clause asymmetries in the Scandinavian languages (MECAS), Lund, April 14-15.

Johannessen, Janne Bondi. To appear. Attrition in an American Norwegian heritage language speaker. In Johannessen \& Salmons (eds.).

Johannessen, Janne Bondi \& Signe Laake. 2011. Den amerikansk-norske dialekten i Midtvesten. In Studier i dialektologi og sociolingvistik. Föredrag ved Nionde nordiska dialektologkonferensen i Uppsala 18. - 20. augusti 2010, eds. Edlund, Lars-Erik, Lennart Elmevik \& Maj Reinhammar, 177-186. Uppsala:Acta Academiae Regiae Gustavi Adolphi CXVI.

Johannessen, Janne Bondi, Joel Priestley, Kristin Hagen, Tor Anders Åfarli \& Øystein Alexander Vangsnes. 2009. 'The Nordic Dialect Corpus - an Advanced Research Tool,' In Proceedings of the 17th Nordic Conference of Computational Linguistics NODALIDA 2009, NEALT Proceedings Series Volume 4, eds. Jokinen, Kristiina and Eckhard Bick. Tartu: University of Tartu Electronic Press.

Johannessen, Janne Bondi \& Signe Laake. 2012. Østnorsk som norsk fellesdialekt i Midtvesten. Norsk Lingvistisk Tidsskrift 30:2, 365-380.

Johannessen, Janne Bondi \& Signe Laake. To appear. Eastern Norwegian as a common Norwegian dialect in the Midwest. Journal of Language Contact. 
Johannessen, Janne Bondi \& Joseph Salmons (eds.). To appear. Germanic Heritage Language in America. John Benjamins.

Julien, Marit. 2007. Embedded V2 in Norwegian and Swedish. Working Papers in Scandinavian Syntax 80.

Julien, Marit. 2008. Så vanleg at det kan ikkje avfeiast: om V2 i innføydde setningar. In Språk i Oslo. Ny forskning omkring talespråk. (eds.) Janne Bondi Johannessen \& Kristin Hagen, 159-171. Oslo: Novus forlag.

Julien, Marit. 2009. The force of the argument. Working Papers in Scandinavian Syntax 84. Karstadt, Angela. 2003. Tracking Swedish-American English. A Longitudinal Study of Linguistic Variation and Identity. Uppsala: University of Uppsala.

Kerswill, Paul (2003). Dialect levelling and geographical diffusion in British English. In D. Britain and J. Cheshire (eds.) Social dialectology. In honour of Peter Trudgill, 223243Amsterdam: John Benjamins.

Kroch, A. 1989. Reflexes of Grammar in Patterns of Language Change. Language Variation and Change 1:199-244.

Larsson, Ida, Sofia Tingsell, Maia Andréasson, Benjamin Lyngfelt \& Jenny Nilsson. 2012. Amerikasvenska förr och nu. Norsk Lingvistisk Tidskrift 30:12, 365-380.

Larsson, Ida, Sofia Tingsell \& Maia Andréasson. To appear. Variation and Change in American Swedish. In Johannessen \& Salmons (eds.).

Larsson, Ida \& Janne Bondi Johannessen. To appear. Embedded Word Order in Heritage Scandinavian. In The 11th International Conference of Nordic and General Linguistics, eds. Hilpert, Martin, Janet Duke, Christine Mertzlufft, Jan-Ola Östman, and Michael Rießler. Berlin: Linguae et Litterae, Mouton de Gruyter.

Lightfoot, David. 1999. The Development of Language: Acquisition Change and Evolution. Oxford: Blackwell. 
Lightfoot, D. \& M. Westergaard. 2007. Language Acquisition and Language Change: Interrelationships. Language and Linguistics Compass 1:396-416.

Montrul, S. 2005. Second language acquisition and first language loss in adult early bilinguals: Exploring some differences and similarities. Second Language Research 21: 3, 199-249.

Montrul, Silvina. 2008. Incomplete Acquisition in Bilingualism. Re-examining the Age Factor. John Benjamins.

Montrul, Silvina, Rebecca Foote \& Silvia Perpinán. 2008. Gender Agreement in Adult Second Language Learners and Spanish Heritage Speakers: The Effect of Age and Context of Acquisition. Language Learning 58:3, 503-553.

Müller, N. and Hulk, A. 2001. Crosslinguistic influence in bilingual language acquisition: Italian and French as recipient languages. Bilingualism: Language and Cognition 4: 153.

Nützel, Daniel \& Joseph Salmons. 2011. Structural stability and change in language contact: Evidence from American German. Language and Linguistics Compass 5:705-717. Petzell, Erik Magnusson. 2011. OV-ordföljd i svenskans historia. Arkiv för Nordisk filologi 126:141-191.

Platzack, Christer. 2001. The vulnerable C-domain. Brain and Language 77: 364-377. Polinsky Maria. 1995. American Russian: Language Loss Meets Language Acquisition. In: Formal Approaches to Slavic Linguistics. Cornell Meeting. Ann Arbor: Michigan Slavic Publications.

Polinsky Maria. 2006. Incomplete acquisition: American Russian. Journal of Slavic Linguistics 14:191-262.

Polinsky, Maria. 2008. Gender under incomplete acquisition: Heritage speakers' knowledge of noun categorization. Heritage Language Journal 6(1): 40-71. 
Putnam, Michael \& Liliana Sánchez. Ms. What's so incomplete about incomplete acquisition? - A prolegomenon to modelling heritage language grammars. Ms. Penn State University \& Rutgers University.

Richards, Marc. 2008. Two Kinds of Variation in a Minimalist System. In Varieties of Competition, Fabian Heck, Gereon Müller \& Jochen Trommer (eds.). Universität Leipzig. 133-162.

Rizzi, Luigi. 1997. The Fine Structure of the Left Periphery. In Elements of Grammar. Dordrecht, ed. Liliane Haegeman, 281-337. Dordrecht: Kluwer.

Roeper, Tom. Universal Bilingualism. Bilingualism: Language and Cognition 2(3): 169-186. Rosenkvist, Henrik. 2011. Verb Raising and Referential Null Subjects in Övdalian. Working Papers in Scandinavian Syntax 88:1-20.

Sandøy, Helge. 2008. Noen syntaktiske “avvik” i norsk. In Banebryter og brobygger $i$ andrespråksfeltet. En samling artikler i anledning Jon Erik Hagens 60-årsdag, eds. Carlsen, Cecilie, Eli Moe, Reidun Andersen \& Kari Tenfjord. Oslo: Novus forlag. Seliger $\square$, Herbert W. \& Robert M. Vago. 1991. $\square$ First Language Attrition. Cambridge: Cambridge University Press.

Sorace, A. 2004. Native language attrition and developmental instability at the syntaxdiscourse interface: data, interpretations and methods. Bilingualism: Language and Cognition 7: 143-145.

Sorace, Antonella \& Serratrice, Ludovica. 2009. Internal and external interfaces in bilingual language development: Beyond structural overlap. International Journal of Bilingualism 13 (2): 195-210.

Sundquist, John D. 2002. Morphosyntactic Change in the History of the Mainland Scandinavian Languages. Ph.D. dissertation, Indiana University. 
Taranrød, Beate. 2011. Leddstillingen i relativsetninger i amerikansknorsk. Master's thesis, Department of Linguistics and Nordic Studies. Oslo: University of Oslo.

Thráinsson, Höskuldur. 2003. Syntactic variation, historical development, and minimalism. In Minimalist syntax, (ed.), Randalll Hendrick, 152-191. Oxford: Blackwell.

Thráinsson, Höskuldur. 2010. Predictable and unpredictable sources of variable verb and adverb placement in Scandinavian. Lingua 120: 1062-1088.

Tsimpli, Ianthi Maria, Sorace, Antonella, Heycock, Caroline \& Filiaci, Francesca. 2004. First language attrition and syntactic subjects: a study of Greek and Italian near-native speakers of English. International Journal of Bilingualism 8: 257-277.

Yang, Charles. 2000. Internal and External Forces in Language Change. Language Variation and Change 12: 231-250.

Yang, Charles. 2002. Knowledge and Learning in Natural Language. Oxford: Oxford University Press.

Yang, Charles. 2010. Three factors in language variation. Lingua 120, 1160-1177

Vangsnes, Øystein A. 2006. Microparameters for Norwegian wh-grammars. Linguistic Variation Yearbook; Vol:5, 187 - 226.

Vikner, Sten. 1995. Verb Movement and Expletive Subjects in the Germanic Languages. New York \& Oxford: Oxford University Press.

Waldmann, Christian, 2008. Input och output. Ordföljd i svenska barns huvudsatser och bisatser. Dissertation. Lund: University of Lund.

Westergaard, Marit, 2006. Triggering V2: The Amount of Input Needed for Parameter Setting in a Split-CP Model of Clause Structure. In Language Acquisition and Development: Proceedings of GALA 2005, eds. Adriana Belletti et al, 658-671. Cambridge.

Westergaard, Marit. 2009. The Acquisition of Word Order. Micro-Cues, information structure and economy. Amsterdam: John Benjamins. 
Westergaard, Marit. 2013. 'The Acquisition of Linguistic Variation: Parameters vs. Microcues.' In In Search of Universal Grammar, ed. Terje Lohndal, 275-298. Amsterdam: John Benjamins.

Westergaard, Marit \& Øystein Vangsnes. 2005. Wh-questions, V2, and the left periphery of three Norwegian dialects. Journal of Comparative Germanic Linguistics 8:117-158.

Westergaard, Marit \& Kristine Bentzen, 2007. The (non-)effect of input frequency on the acquisition of word order in Norwegian embedded clauses. In Frequency Effects in Language Acquisition. Defining the limits of frequency as an Explanatory Concept, eds. Insa Gülzow \& Natalia Gagarina, 271-306. Berlin: Mouton de Gruyter.

Wexler, Kenneth. 1999. Very early parameter setting and the unique checking constraint: A new explanation of the optional infinitival stage. In Language Acquisition: Knowledge Representation and Processing, eds. A. Sorace, C. Heycock \& Richard Shillock (eds.), 2379. Special issue of Lingua.

Wiklund, Anna-Lena, Kristine Bentzen, Gunnar Hrafn Hrafnbjargarson \& Porbjörg Hróarsdóttir. 2009. On the distribution and illocution of V2 in Scandinavian thatclauses. Lingua 119:1914-1938.

Websites:

Norwegian in America: http://www.tekstlab.uio.no/nota/NorAmDiaSyn/english/index.html Swedish in America: https://sites.google.com/site/svenskaniamerika/home/english 